\title{
PENGARUH KONSENTRASI ASAP CAIR DAN LAMA PERENDAMAN TERHADAP MUTU ORGANOLEPTIK IKAN KAYU (KATSUO-BUSHI)
}

\author{
Yisia Katiandagho ${ }^{1}$, Siegfried Berhimpon ${ }^{2}$ dan Albert Royke Reo ${ }^{2}$ \\ ${ }^{1)}$ Mahasiswa pada Program Studi Teknologi Hasil Perikanan FPIK Unsrat Manado \\ ${ }^{2)}$ Staf pengajar pada Program Studi Teknologi Hasil Perikanan FPIK Unsrat Manado \\ Email: icha.katiandagho@yahoo.com
}

\begin{abstract}
Dried smoked skipjack or better known as Katsuo-bushi is a popular type of smoked fish in Japan. It has a distinctive flavor and widely used in traditional Japanese cuisine. The weakness of commercial Katsuo-bushi nowadays is the high content of Polycyclic Aromatic Hydrocarbon (PAH) (may exceed $10 \mathrm{ppb}$ ). Recent study examined the low PAH Katsuo-bushi product made with liquid smoke. However, the sensory acceptance of this product has not been determined yet. The purpose of this study was to determine the effect of liquid smoke concentration $(1 \%, 2 \%$ and $3 \%)$ and soaking time $(10,20$ and $30 \mathrm{~min})$ on the sensory quality of Katsuo-bushi. Duo-trio method was used for sensory evaluation. Additional chemical analysis such as moisture content and $\mathrm{pH}$ were performed. Significant differences were found among liquid smoke Katsuo-bushi product compare to traditional Katsuo-bushi $(\mathrm{P}<0.1)$. Also, it is suggested that the longer the soaking time, the higher the moisture content and $\mathrm{pH}$ value.
\end{abstract}

Keyword: $\quad$ Katsuo-bushi, liquid smoke, Duo trio method.

Ikan kayu atau lebih dikenal dengan Katsuo-bushi adalah sejenis ikan asap yang telah lama dikenal dan memiliki flavor yang khas yang biasanya digunakan pada masakan tradisional di Jepang. Kelemahan ikan kayu yang ada di dunia dewasa ini adalah tingginya kandungan Polycyclic Aromatic Hydrocarbon (PAH) yang melebihi $10 \mathrm{ppb}$. Penelitian terkini (Berhimpon, $d k k$ 2016) meneliti ikan kayu asap cair yang rendah PAH, tetapi belum diteliti tingkat kesukaan secara organoleptik. Penelitian ini adalah untuk mendapatkan ikan kayu asap cair yang rendah PAH tetapi disukai oleh konsumen. Tujuan penelitian ini ialah untuk mengetahui pengaruh konsentrasi asap cair dan lama perendaman terhadap mutu organoleptik ikan kayu asap cair yang dibuat dengan berbagai konsentrasi dan lama perendaman, dan dibandingkan dengan ikan kayu konvensional. Parameter pengamatan ialah analisa organoleptik dengan metode duo trio (Berhimpon, $d k k$. 2005), analisa kadar air dan pH (AOAC, 2005). Hasil penelitian ini menunjukkan bahwa ikan kayu yang direndam dalam asap cair dengan konsentrasi $2 \%$ dan 3\% masing-masing selama 30 dan 10 menit berbeda sangat nyata $(\mathrm{P}<0,1)$ dengan ikan kayu konvensional. Sedangkan perlakuan yang lain sama dengan ikan kayu konvensional. Untuk analisa kadar air dan $\mathrm{pH}$ menunjukkan bahwa lama perendaman memberikan pengaruh yang nyata terhadap nilai kadar air dan pH dari ikan kayu asap cair, dimana semakin lama waktu perendaman dalam larutan asap cair maka semakin tinggi kadar air dan $\mathrm{pH}$ dari ikan kayu tersebut.

Kata Kunci: Ikan kayu (Katsuo-bushi), asap cair, metode duo trio.

\section{PENDAHULUAN}

Ikan kayu atau lebih dikenal dengan Katsuo-bushi adalah salah satu produk ikan asap yang telah lama dikenal dan memiliki flavor yang khas yang biasanya digunakan pada masakan tradisional di Jepang. Pengolahan ikan kayu harus melalui beberapa tahapan atau proses yang cukup unik yaitu, melalui proses perebusan, pengeringan, pengasapan dan penjamuran. Jenis ikan yang umum digunakan adalah ikan Cakalang (Katsuwonus pelamis L.), ikan Tongkol (Euthynnus affinis) dan ikan Tuna (Thunnus sp.). Di Indonesia, ikan kayu diproduksi secara komersial untuk diekspor. Ikan kayu yang dihasilkan berupa arabushi, yaitu ikan yang sudah diasapi dan dikeringkan tanpa dilakukan proses penjamuran sesuai dengan permintaan negara pengimpor, karena biasanya proses penjamuran (fermentasi) dilakukan sendiri secara khusus di negara pengimpor.

Ikan kayu dapat juga mengalami proses kerusakan namun, bila dibandingan dengan produk lain kerusakan yang terjadi lebih lambat, karena ikan kayu sendiri memiliki kadar air yang rendah bahkan sangat rendah 
yaitu sekitar 15-17\%. Seperti diketahui bersama, bahwa kadar air produk yang rendah dapat menghambat aktivitas mikroba yang menyebabkan proses kerusakan. Berhimpon $d k k .$. (2014), mengatakan bahwa kelemahan ikan kayu yang ada di dunia dewasa ini adalah tingginya kandungan Polycyclic Aromatic Hydrocarbon (PAH) yang melebihi $10 \mathrm{ppb}$, yaitu standar yang diberikan oleh negara-negara pengimpor. Karena itu, perlu dicari teknologi baru untuk memproduksi ikan kayu yang rendah PAH.

Asap cair merupakan senyawa-senyawa yang menguap secara simultan dari reaktor panas melalui teknik pirolisis (penguraian dengan panas) dan berkondensasi pada sistem pendingin (Simon et al., 2005 dalam Ayudiarti dan Sari, 2010). Pengolahan ikan menggunakan asap cair memiliki beberapa kelebihan yaitu mudah diterapkan atau praktis penggunaannya, flavor produk lebih seragam dan dapat digunakan berulang-ulang, lebih efesien dalam penggunaan bahan pengasap, polusi lingkungan dapat diperkecil, dan yang paling penting senyawa karsinogen yang terbentuk dapat diminimalkan. Asap cair berdasarkan kegunaannya dapat diaplikasikan ke berbagai bahan makanan tak terkecuali ikan yang akan diolah atau dibuat menjadi ikan kayu, (Simon et al., 2005 dalam Ayudiarti dan Sari, 2010).

Berhimpon, dkk. (2016) telah meneliti pembuatan ikan kayu asap cair dan mendapatkan kandungan $\mathrm{PAH}<0,25 \mathrm{ppb}$. Penelitian ini merupakan kelanjutan apakah ikan kayu asap cair tersebut dapat diterima oleh konsumen dan dibandingkan dengan ikan kayu konvensional.

Adapun tujuan penelitian ini adalah untuk mengetahui pengaruh konsentrasi asap cair dan lama perendaman terhadap mutu organoleptik ikan kayu. Serta mengetahui pada konsentrasi berapa persen ikan kayu asap cair paling disukai.

\section{METODOLOGI PENELITIAN}

Penelitian ini dilakukan di Laboratorium Penanganan dan Pengolahan Hasil Perikanan dan Laboratorium Pengendalian Mutu Hasil Perikanan Fakultas Perikanan dan Ilmu Kelautan Universitas Sam Ratulangi.

\section{Bahan dan Alat}

1. Untuk Pembuatan Ikan Kayu Asap Cair:
Ikan Cakalang sebanyak $\pm 10 \mathrm{~kg}$, asap cair (konsentrasi 1, 2 dan 3\%), akuades, thermocouple, pisau, telenan, timbangan, gelas ukur, wadah untuk ikan, kompor, lemari pengering.

2. Untuk Analisa Organoleptik (Duo Trio):

Ikan kayu asap cair, ikan kayu konvensional, air minum sebagai penetral rasa, pisau, wadah sampel, bilik pencicipan dan formulir penilaian.

3. Untuk Analisa Kadar Air:

Sampel ikan kayu asap cair sebanyak 2 gram untuk setiap perlakuan dan ulangan, cawan porselin, oven, desikator, mortal dan pastel, timbangan analitik dan penjepit.

4. Untuk Analisa pH:

Sampel ikan kayu asap cair sebanyak 5 gram masing-masing perlakuan dan ulangan, larutan buffer $\mathrm{pH} 4$ dan $\mathrm{pH}$ 7, akuades, $\mathrm{pH}$ meter (merk Adwa tipe AD 1000), timbangan analitik, mortal dan pestle, dan beaker glass.

\section{Perlakuan dan Rancangan Percobaan}

Dalam penelitian ini perlakuan yang akan digunakan meliputi:

1. Konsentrasi larutan asap cair $(\mathrm{A})$ :

$$
\begin{aligned}
& -1 \%\left(A_{1}\right) \\
& -2 \%\left(A_{2}\right) \\
& -3 \%\left(A_{3}\right)
\end{aligned}
$$

2. Waktu perendaman dalam asap cair (B):

- 10 menit $\left(B_{1}\right)$

- 20 menit $\left(B_{2}\right)$

- 30 menit $\left(\mathrm{B}_{3}\right)$

Temperatur dan lama pengeringan yang dipakai ialah $85^{\circ} \mathrm{C}$ selama 2 jam. Untuk melihat pengaruh dari setiap perlakuan, maka data yang di peroleh dianalisa dengan menggunakan analisa sidik ragam Rancangan Acak lengkap (RAL) yang disusun secara factorial, dengan 2 kali ulangan untuk setiap perlakuan.

\section{Tata Laksana Penelitian}

Tahapan atau prosedur pembuatan ikan kayu (Katsuo-bushi)asap cair adalah sebagai berikut:

- Ikan Cakalang sebagai bahan baku kurang lebih sebanyak $10 \mathrm{~kg}$, pertama-tama dilakukan penyiangan dimana insang dan isi perut dikeluarkan.

- Kemudian ikan yang sudah disiangi, dicuci bersih lalu direbus selama 90 menit dengan temperatur perebusan $80-90^{\circ} \mathrm{C}$ (temperatur 
diukur dengan menggunakan thermocouple).

- Setelah perebusan, ikan didinginkan kurang lebih selama 30 menit lalu ikan di fillet menjadi empat bagian.

- Ikan yang sudah difilet dilakukan pembersihan kulit dan pencabutan tulang, kemudian direndam dalam larutan asap cair dengan konsentrasi masing-masing 1\%, 2\% dan $3 \%$ selama 10 menit, 20 menit dan 30 menit.

- Selanjutnya, ikan dikeringkan dalam oven pengering selama 2 jam pada temperatur $85^{\circ} \mathrm{C}$.

- Setelah pengeringan 2 jam pertama ikan dikeluarkan dan didiamkan selama 4 jam dan direndam kembali dalam larutan asap cair dengan konsentrasi dan lama perendaman yang sama, kemudian dikeringkan kembali pada temperatur $651^{\circ} \mathrm{C}$ selama 2 jam.

- Seterusnya, pengeringan dilakukan kurang lebih sebanyak 7 kali hingga memperoleh kadar air yang diinginkan (antara 15-17\%).

- Produk ikan kayu yang sudah jadi, kemudian dianalisa di laboratorium dengan melakukan uji kadar air, pH, organoleptik pembedaan (uji duo trio).

\section{Parameter Pengamatan}

Analisa Duo Trio (Berhimpon, $d k k$. 2005)

Analisa organoleptik ikan kayu asap cair menggunakan uji Duo Trio yang merupakan uji pembedaan, dimana dalam uji ini contoh yang disajihkan berjumlah 3 contoh yang 2 diantaranya memiliki sifat sensoris yang sama, sedangkan satu contoh adalah contoh baku atau sebagai reference.

Uji ini bertujuan untuk mendeteksi perbedaan yang sangat kecil dari bahan uji dan atau melihat persamaan antara bahan uji dengan contoh baku. Dalam uji ini, contoh dibandingkan dengan ikan kayu konvensional produksi PT. Celebes Mina Pratama sebagai contoh baku. Pengujian dilakukan secara sensoris meliputi warna, tekstur, rasa, bau dan penampakan.

\section{Analisa Kadar Air (AOAC, 2005)}

Analisis kadar air dilakukan dengan menggunakan metode oven. Prinsipnya adalah menguapkan molekul air $\left(\mathrm{H}_{2} \mathrm{O}\right)$ bebas yang ada dalam sampel.Kemudian sampel ditimbang sampai didapat bobot konstan yang diasumsikan semua air yang terkandung dalam sampel sudah diuapkan. Selisih bobot sebelum dan sesudah pengeringan merupakan banyaknya air yang diuapkan.

\section{Analisa pH (AOAC, 2005)}

Dalam penelitian ini analisa kadar $\mathrm{pH}$ ikan kayu asap cair menggunakan alat $\mathrm{pH}$ meter (merk Adwa tipe AD 1000) dengan prosedur analisa pH (AOAC, 2005). Prosedur analisa dilakukan dengan menggunakan AOAC (2005).

\section{HASIL DAN PEMBAHASAN}

\section{Mutu Organoleptik (Analisa Duo Trio) Ikan Kayu Asap Cair}

Analisa organoleptik dengan menggunakan uji duo trio ini dipakai untuk melihat perbedaan terkecil terhadap dua sampel yang berbeda.Penilaian ini dilakukan dengan menggunakan panelis terlatih, dan formulir atau lembar penilaiandengan melihat perbedaan rasa, bau, warna, tekstur dan kenampakan.Sebanyak 15 panelis yang terdiri dari mahasiswa yang sudah terlatih digunakan dalam penelitian. Hasil yang diperoleh adalah sebagai berikut:

\section{Rasa}

Dari respon 15 panelis, didapatkan data yang dibandingkan dengan tabel two tail ialah ikan kayu yang direndam dalam larutan asap cair dengan konsentrasi 2\% selama 30 menit memiliki rasa yang berbeda nyata $(\mathrm{P}<0,5)$ dibandingkan dengan contoh baku (ikan kayu konvensional). Ikan kayu yang direndam dalam larutan asap cair dengan konsentrasi 3\% selama 10 menit memiliki sifat sensoris rasa yang sangat signifikan $(* *)$ atau berbeda sangat nyata $(\mathrm{P}<0,1)$ dibandingkan dengan contoh baku (ikan kayu konvensional). Perlakuan yang lain tidak berbeda nyata (non signifikan).

Ini berarti perlakuan yang lain mempunyai rasa yang sama dengan ikan kayu konvensional, sedangkan ikan kayu asap cair yang direndam dengan konsentrasi $2 \%$ selama 30 menit dan $3 \%$ selama 10 menit memiliki sifat sensoris untuk rasa yang berbeda dari ikan kayu konvensional. Karena duo trio ini dibandingkan dengan tabel two tail, sehingga panelis dapat memberikan keterangan atau kesan tambahan terhadap sampel. Dari kesan tambahan, semua panelis yang menilai kedua sampel tersebut menyatakan bahwa kedua sampel tersebut lebih enak dari ikan kayu konvensional, dimana rasa dari ikan kayu asap 
cair tersebut mendapat respon yang tinggi dari panelis.

\section{Bau}

Dari respon 15 panelis, didapat data yang dibandingkan dengan tabel two tail ialah ikan kayu yang direndam dalam larutan asap cair dengan konsentrasi $1 \%$ selama 20 dan 30 menit; $2 \%$ dan $3 \%$ selama 20 menit memiliki bau yang berbeda nyata $(\mathrm{P}<0,5)$ dengan ikan kayu konvensional. Ikan kayu yang direndam dalam larutan asap cair dengan konsentrasi $2 \%$ selama 30 menit memiliki bau yang sangat signifikan $(* *)$ atau berbeda sangat nyata $(\mathrm{P}<0,1)$ dibandingkan dengan ikan kayu konvensional. Sedangkan, perlakuan yang lain tidak berbeda nyata (non signifikan).

Ini berarti perlakuan yang lain mempunyai bau yang sama dengan ikan kayu konvensional, sedangkan ikan kayu asap cair yang direndam dengan konsentrasi 1\%, 2\% dan $3 \%$ selama 20 dan 30 menit memiliki bau yang berbeda dari ikan kayu konvensional. Dimana, semua panelis yang menilai sampel tersebut menyatakan bahwa sampel tersebut mempunyai bau yang lebih enak dari ikan kayu konvensional, oleh sebab itu mendapat respon yang tinggi dari panelis.

\section{Warna}

Dari 15 respon panelis, diperoleh data yang dibandingkan dengan tabel two tail yaitu, ikan kayu yang direndam dalam larutan asap cair dengan konsentrasi $1 \%$ selama 20 dan 30 menit; konsentrasi 2\% selama 30 menit memiliki warna yang berbeda nyata $(\mathrm{P}<0,5)$ dibandingkan dengan ikan kayu konvensional. Ikan kayu yang direndam dalam larutan asap cair dengan konsentrasi 3\% selama 30 menit memiliki warna yang sangat signifikan $(* *)$ atau yang berbeda sangat nyata $(\mathrm{P}<0,1)$ dibandingkan dengan ikan kayu konvensional. Perlakuan yang lainnya tidak berbeda nyata (non signifikan).

Ini berarti perlakuan yang lain mempunyai warna yang sama dengan ikan kayu konvensional. Sedangkan, ikan kayu asap cair yang direndam dengan konsentrasi 1, 2 dan 3\% selama 20 dan 30 menit memiliki sifat sensoris untuk warna yang berbeda dengan ikan kayu konvensional. Dimana, semua panelis yang menilai sampel tersebut menyatakan bahwa sampel tersebut memiliki warna yang lebih baik dari ikan kayu konvensional karena, ikan kayu asap cair tersebut mendapat respon yang tinggi dari panelis.

\section{Tekstur}

Dari respon 15 panelis, didapatkan data yang dibandingkan dengan tabel two tail ialah untuk 9 kombinasi perlakuan memiliki tekstur yang sangat signifikan $(* *)$ atau berbeda sangat nyata $(\mathrm{P}<0,1)$ dibandingkan dengan ikan kayu konvensional. Hal ini berarti ikan kayu asap cair dengan 9 kombinasi perlakuan memiliki tekstur yang berbeda dengan ikan kayu konvensional. Semua panelis yang menilai semua sampel dengan perlakuan yang berbeda menyatakan bahwa sampel tersebut memiliki tekstur lebih yang keras dibandingkan dengan ikan kayu konvensional. Tekstur keras adalah salah satu ciri khas dari ikan kayu dimana, tekstur keras tersebut dihasilkan dari proses pengasapan dan pengeringan yang berlangsung sangat lama pada temperatur tertentu.

\section{Kenampakan}

Dari respon 15 panelis, didapatkan data yang dibandingkan dengan tabel two tail, yaitu ikan kayu yang direndam dalam larutan asap cair dengan konsentrasi $2 \%$ selama 30 menit memiliki kenampakan yang berbeda nyata $(\mathrm{P}<0,5)$ dibandingkan dengan ikan kayu konvensional. Ikan kayu yang direndam dalam larutan asap cair dengan konsentrasi 3\% selama 10 menit memiliki sifat sensoris untuk kenampakan yang sangat signifikan $(* *)$ atau berbeda sangat nyata $(\mathrm{P}<0,1)$ dibandingkan dengan ikan kayu konvensional. Perlakuan yang lain tidak berbeda nyata (non signifikan).

Ini berarti perlakuan yang lain mempunyai kenampakan yang sama dengan ikan kayu konvensional, sedangkan ikan kayu asap cair yang direndam dengan konsentrasi $2 \%$ selama 10 dan 30 menit memiliki kenampakan yang berbeda dibandingkan dengan ikan kayu konvensional. Dimana, semua panelis yang menilai kedua sampel tersebut menyatakan bahwa kedua sampel tersebut memiliki kenampakan yang lebih baik dari ikan kayu konvensional karena, ikan kayu asap cair tersebut mendapat respon yang tinggi dari panelis.

\section{Kadar Air dan pH Ikan Kayu Asap Cair}

Kadar air ikan kayu asap cair adalah kadar air ikan kayu setelah pengeringan ke tujuh. Sebelumnya telah dilakukan analisa 
kadar air mulai pengeringan ke empat sampai pada pengeringan ke tujuh. Hal ini dilakukan untuk mengetahui kadar air dari masing-masing ikan kayu asap cair pada setiap proses pengeringan.

Nilai rata-rata kadar air ikan kayu asap cair yang digunakan ialah kadar air pada pengeringan ke tujuh, dapat dilihat pada Gambar 1. Dimana, pada pengeringan ke tujuh sudah mencapai kadar air yang diinginkan.

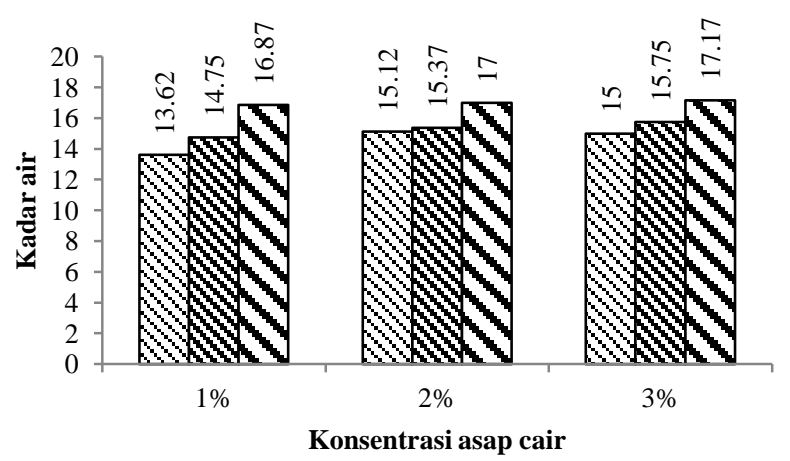

Keterangan:

$W$ = Ikan kayu yang direndam dalam larutan asap cair selama 10 menit $\mathbf{W}$ = Ikan kayu yang direndam dalam larutan asap cair selama 20 menit W = Ikan kayu yang direndam dalam larutan asap cair selama 30 menit

\section{Gambar 1. Histogram kadar air ikan kayu asap} cair

Berdasarkan histogram pada Gambar 1 dilihat bahwa nilai rata-rata kadar air tertinggi adalah ikan kayu asap cair yang direndam dengan konsentrasi $1 \%, 2 \%$ dan $3 \%$ selama 30 menit dengan kisaran $16,88 \%$ sampai $17,17 \%$. Sedangkan, nilai rata-rata kadar air terendah adalah ikan kayu asap cair yang direndam dengan konsentrasi $1 \%, 2 \%$ dan $3 \%$ selama 10 menit dengan kisaran $13,63 \%$ sampai $15,13 \%$.

Dari hasil tersebut dapat dilihat bahwa, lama perendaman dapat mempengaruhi akan kadar air ikan kayu asap cair tersebut. Hal ini berarti, ikan kayu asap cair dapat diterima melihat dari kandungan kadar airnya. Seperti yang diketahui bahwa meningkat atau menurunnya kadar air bahan pangan merupakan dampak dari kecenderungan adanya perbedaan kelembaban udara sekitarnya, dengan kata lain kandungan kadar air bahan pangan akan berubah-ubah sesuai dengan lingkungannya. Namun, untuk kadar air ikan kayu asap cair yang rendah akan mempengaruhi berat produk.

Rendahnya kadar air suatu bahan pangan mempengaruhi masa simpan atau mutu bahan pangan tersebut. Dimana, semakin rendahnya kadar air bahan pangan yang diasap menyebabkan mutu bahan pangan semakin meningkat atau masa simpannya cukup panjang. Mutu adalah faktor yang sangat penting dan perlu diperhatikan oleh para produsen dan konsumen. Oleh sebab itu setiap bahan pangan memiliki standar mutu yang menjadi patokan dalam memproduksi suatu produk pangan.

Sama dengan kadar air, lama perendaman juga memberikan pengaruh yang nyata dimana, derajat keasaman $(\mathrm{pH})$ yang dimiliki oleh ikan kayu yang direndam dalam larutan asap cair dengan konsentrasi 1\%, 2\% dan 3\% masing-masing memiliki nilai rata-rata $\mathrm{pH}$ tertinggi pada perendaman 30 menit yaitu, antara 5,20-5,3. Sedangkan untuk nilai rata-rata terendah ialah pada perendaman 10 menit yaitu berkisar 5,05-5,12. Untuk lebih jelasnya nilai rata-rata $\mathrm{pH}$ ikan kayu dapat dilihat pada Gambar 2. Dari hasil tersebut dapat dilihat bahwa semakin lama direndam maka semakin tinggi nilai $\mathrm{pH}$ yang diperoleh.

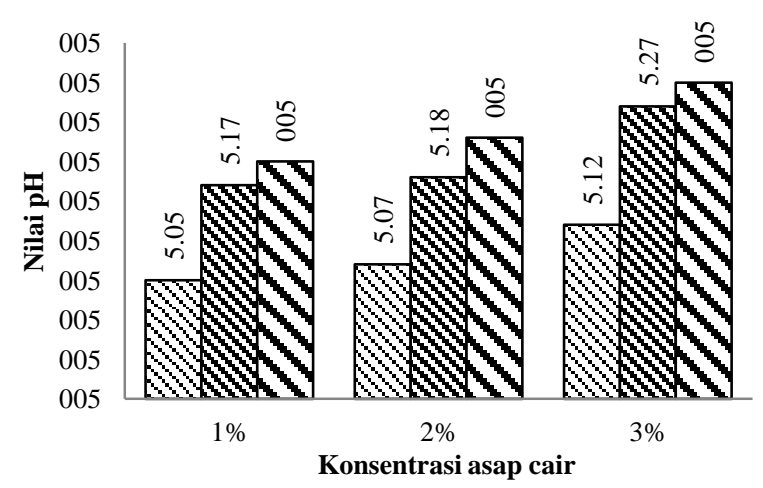

Keterangan:

$\mathbb{N}$ = Ikan kayu yang direndam dalam larutan asap cair selama 10 menit $\mathbf{N}$ = Ikan kayu yang direndam dalam larutan asap cair selama 20 menit V = Ikan kayu yang direndam dalam larutan asap cair selama 30 menit

\section{Gambar 2. Histogram pH ikan kayu asap cair}

Menurut Berhimpon (1974) bahwa, tinggi rendahnya nilai $\mathrm{pH}$ dipengaruhi oleh lamanya pengasapan, dimana pada pengasapan yang berlangsung lebih lama, maka unsur asap yang terserap dan melekat pada produk lebih banyak, demikian juga senyawa asam yang terserap juga meningkat. Pengawetan dengan asap cair memiliki $\mathrm{pH}$ bahan pangan sekitar 6,0 dimana pada $\mathrm{pH}$ netral atau bahkan $\mathrm{pH}$ yang lebih rendah atau bahan pangan yang bersifat asam diketahui bahwa pertumbuhan mikroorganisme dapat terhambat (Wisniewski dan Manrer, 1979 dalam Pelokang, 2010). 


\section{KESIMPULAN}

Dari hasil yang diperoleh dan dibahas maka dapat ditarik kesimpulan yakni, sebagai berikut:

1. Hasil uji mutu organoleptik ikan kayu asap cair dengan metode duo trio ialah ikan kayu asap cair yang berbeda sangat nyata $(\mathrm{P}<1)$ dan lebih enak dari ikan kayu konvensional adalah ikan kayu asap cair yang direndam dengan konsentrasi $2 \%$ dan 3\% selama 30 dan 10 menit. Sedangkan perlakuan yang lain sama dengan ikan kayu konvensional.

2. Hasil uji kadar air dan pH ikan kayu asap cair menunjukkan bahwa lama perendaman dapat memberikan pengaruh yang nyata terhadap kadar air dan $\mathrm{pH}$ dimana, semakin lama waktu perendaman pada larutan asap cair maka semakin tinggi kadar air dan $\mathrm{pH}$ ikan kayu tersebut.

\section{DAFTAR PUSTAKA}

Afrianto E dan Liviawaty., 1989., Pengawetan dan Pengolahan Ikan., Penerbit Kanisius., Yogyakarta.

[AOAC] Association of Official Analytical and Chemistry., 2005., Official Methods of Analysis.

Atmaja Adi Kusuma., 2009., Aplikasi Asap Cair Redestilisasi Pada Karakterisasi Kamaboko Ikan Tongkol (Euthynnus affinis) Ditinjau Dari Tingkat Keawetan dan Kesukaan Konsumen., Skripsi., Fakultas Pertanian Universitas Sebelas Maret., pdf., 8/30/2016/10:41am., https://core.ac.uk/download/ pdf/12350293.pdf.

Ayudiarti Lestari Diah dan Sari Nurbaya Rodiah., 2010., Asap Cair dan Aplikasinya Pada Produk Perikanan., Squalen Vol. 5 No. 3., Balai Besar Riset Pengolahan Produk dan Bioteknologi Kelautan dan Perikanan; 5/7/2016/12:28pm.,http://www.bbp4b.litbang.kkp.go.i $\mathrm{d} /$ squalenbulletin/index.php/squalen/article/download/ $53 / 33$.

Berhimpon S., 1974., Pengaruh Bahan Pengawet Kimia dan Lama Penyimpanan Terhadap Mutu Ikan Mas (Caprynus carpio) Asap Yang Disimpan Pada Temperatur Kamar., Thesis., Fakultas Perikanan., Universitas Sam Ratulangi - Afiliasi Institut Pertanian Bogor.

Berhimpon S., Dotulong V., Makapedua D. M., 1993. Studi Tentang Limbah Pabrik Ikan Kayu PT. Harmas Sahabat Perkasa., Laporan Penelitian., Berita Fakultas Perikanan., Vol. 3 No. 1 1993., Universitas Sam ratulangi., Manado.

Berhimpon S; Ijong G.F; Dien A.H; Damongilala J.L; Kaseger E.B; Salindeho N., 2005., Penilaian Indera., Penuntun Praktikum., Laboratorium Penanganan dan Pengolahan Hasil Perikanan., Fakultas Perikanan dan Ilmu Kelautan., Universitas Sam Ratulangi., Manado.

Berhimpon S., Dien H.A., Montolalu R.I., 2003., Processing And The Prospect Of Katsuo-bushi (Ikan Kayu) Of North Sulawesi, Indonesia., Journal of International., Presented at The DGHE-JSPS
International Workshop on "The Quality Improvement of Traditional Fisheries Products in Asian Region"., Semarang, 25-26 August 2003.

Berhimpon S., Dien H.A., Mentang F., 2014., Pengembangan Produk Eksotik Ikan Fufu Non Karsinogenik dengan Memanfaatkan Limbah Industri Perikanan dalam Upaya Meningkatkan Nilai Tambah Ekonomi., Laporan Kemajuan., Penelitian Prioritas Nasional Masterplan Percepatan dan Perluasan Pembangunan Ekonomi Indonesia 2011-2025 (PENPRINAS MP3EI)., Universitas Sam Ratulangi., Manado.

Berhimpon S., Montolalu R.I., Dien H.A., Mentang F., 2016., Scale Up Produksi Ikan Kayu (Katsuo-bushi) Rendah Kandungan Polycyclic Aromatic Hydrocarbon (PAH) Dengan Menggunakan Asap Cair., Laporan Penelitian., PUSNAS., Universitas Sam Ratulangi., Manado.

Buckle K.A., Edwards R.A., Fleet G.H., dan Woottor M., 1987.,Ilmu Pangan., Department of Education And Culture Directorate General of Higher Education., International Development Program of Australian Universities And Colleges., Universitas Indonesia., Jakarta.

Fadhilah L. N., 2010., Pendugaan Pertumbuhan dan Mortalitas Ikan Cakalang (Katsuwonus pelamis Linnaeus, 1758) yang Didaratkan di PPN Pelabuhan Ratu, Kabupaten Sukabumi, Provinsi Jawa Barat., Skripsi., Fakultas Perikanan dan Ilmu Kelautan., Institut Pertanian Bogor., Bogor.

Giyatmi., 1998., Isolasi dan Identifikasi Kapang Pada Pembuatan Ikan Kayu (Katsuo-bushi) Ikan Cakalang (Katsuwonus pelamis) Dengan Fermentasi Alami., Thesis., Program Pasca Sarjana Institut Pertanian Bogor., Bogor.

Julianti Elisa., 2014., Penuntun Praktikum Pengetahuan Bahan Pangan., Program Studi Ilmu dan Teknologi Pangan Fakultas Pertanian., Universitas Sumatera Utara., Medan., pdf., 7/25/2016/12:39am., https://elisajulianti.files.wordpress.com/2013/10/penu ntun-praktikum-pengetahuan-bahan-pangan.pdf.

Kaparang Rita, Harikedua Silvana D, Suwetja I Ketut., 2013., Penentuan Mutu Ikan Tandipang (Dussumeiria acuta C.V) Asap Kering Selama Penyimpanan Temperatur Kamar., Jurnal., Fakultas Perikanan dan Ilmu Kelautan Universitas Sam Ratulangi., Manado.

Keno J., 2014., Sanitasi Pengolahan Ikan Kayu Di PT.Celebes Minapratama, Kelurahan Wangurer Timur Kota Bitung, Sulawesi Utara., Laporan Hasil Magang., Fakultas Perikanan dan Ilmu Kelautan Universitas Sam Ratulangi., Manado.

Leha A. Maria., 2010.,Aplikasi Asap Cair Sebagai Biopresevativ Dalam Bahan Pangan (Ikan Cakalang Asap)., Seminar Nasional Basic Science II., Fakultas Matematika dan Ilmu Pengetahuan Alam Universitas Pattimura Ambon., http://ejournal.unpatti.ac.id/ ppr_paperinfo_Ink.php?id=555.

Pelokang D., 2010., Pengaruh Konsentrasi dan Cara Pemberian Asap Cair Terhadap Mutu Ikan Julungjulung (Hemirhampus marginatus) Asap., Skripsi., Fakultas Perikanan dan Ilmu Kelautan Universitas Sam Ratulangi., Manado. 
Praseptiangga Danar., 2014., Kimia Pangan., Program Studi Ilmu dan Teknologi Pangan., Universitas Sebelas Maret (UNS) Surakarta. http://www.slidesshare.net/fransiskaputeri/materikuliah-kimia-pangan-air.

Sulistijowati R., Djunaedi O., Nurhajati J., Afrianto E., Udin Z., 2011., Mekanisme Pengasapan., UNPAD PRESS., $\quad$ pdf., 10/20/2016/2:42pm., http://respository.iung.ac.id/get/karyailmiah/240/meka nisme-pengasapan-ikan.pdf.

Sunarwati E., 2000., Studi Karakteristik Arabushi dan Ikan Cakalang (Katsuwonus pelamis) Setah Fermentasi kapang., Skripsi., IPB., Bogor.
Syarief R., dan Halid H., 1993.,Teknologi Penyimpanan Pangan., Penerbit Arcan., Jakarta.

Utomo Bagus Sediadi Bandol, Wibowo Singgih, Widianto Tri Nugroho., 2002., Asap Cair., Cara Membuat dan Aplikasinya Pada Pengolahan Ikan Asap., Penebar Swadaya., Depok.

Winarno, F. G dan Fardiaz S., 1980.,Pengantar Teknologi Pangan., PT. Gramedia, Jakarta;

Winarno, F. G. 2002., Kimia Pangan dan Gizi. PT. Gramedia Pustaka Utama., Jakarta. 